\title{
EHMTI-0358. Improved chronic migraine after DTMS
}

\author{
P Scatena ${ }^{1 *}$, G Sette ${ }^{1}$, C Rapinesi ${ }^{1}$, GD Kotzalidis ${ }^{1}$, VR Ferri ${ }^{1}$, S Di Pietro ${ }^{1}$, RN Raccah ${ }^{2}$, S Ferracuti ${ }^{1}$, F Orzi ${ }^{1}$, P Girardi \\ From 4th European Headache and Migraine Trust International Congress: EHMTIC 2014 \\ Copenhagen, Denmark. 18-21 September 2014
}

\section{Background}

The prevalence of chronic migraine (CM) in the general population is around $2 \%$. CM occurs with impaired quality-of-life and frequent medication overuse. Deep transcranial magnetic stimulation (dTMS) of the dorsolateral prefrontal cortex (DLPFC) transiently suppresses central pain perception through reduced functional connectivity between mid-brain and medial thalamus.

\section{Aim}

To assess pain reduction in CM using high frequency rTMS over the left DLPFC.

\section{Method}

Fourteen patients with ICHD-32 CM were randomised to 12 dTMS sessions, delivered on alternate days over bilateral DLPFC with left prevalence $(\mathrm{N}=7 ; 6$ women, 1 man; mean age 45 years) or to treatment as usual (TAU, with anti-migraine agents). All had severe headaches for $\geq 15$ days/month in the last three months, and did not respond to $\geq 3$ preventive medications and to drug overuse treatment. Outcome measures were attack frequency, headache index, and number of medications in the month before (baseline), during treatment, and one month later.

\section{Results}

Patients treated with dTMS, compared to TAU and baseline, had reduced pain intensity, frequency of attacks, and analgesic overuse, during treatment and one month later.

\section{Conclusion}

dTMS presumably improved DLPFC function, thus allowing better executive abilities. This may have enhanced salience-related brain activity, redirecting or diverting attention through the hippocampus, the cingulate cortex, or other pain matrix structures. Results are compatible

"NESMOS (Neuroscience Mental Health and Sensory Organs), "Sapienza" Università di Roma, Roma, Italy

Full list of author information is available at the end of the article with improved brain control over pain sensations. Highfrequency dTMS over bilateral DLPFC improved CM, supporting a role for DLPFC in pain control.

No conflict of interest.

\section{Authors' details}

"NESMOS (Neuroscience Mental Health and Sensory Organs), "Sapienza" Università di Roma, Roma, Italy. ${ }^{2 B r a i n s w a y-I t a l y, ~ " S a p i e n z a " ~ U n i v e r s i t a ̀ ~ d i ~}$ Roma, Roma, Italy.

Published: 18 September 2014

\section{Reference}

1. Manzoni, et al: Curr Pain Headache Rep 2011, 15:170-6.

doi:10.1186/1129-2377-15-S1-M10

Cite this article as: Scatena et al:: EHMTI-0358. Improved chronic migraine after DTMS. The Journal of Headache and Pain 2014 15(Suppl 1):M10.

\section{SpringerOpen ${ }^{\odot}$}

(c) 2014 Scatena et al; licensee Springer. This is an Open Access article distributed under the terms of the Creative Commons Attribution License (http://creativecommons.org/licenses/by/2.0), which permits unrestricted use, distribution, and reproduction in any medium, provided the original work is properly cited.
Submit your manuscript to a SpringerOpen ${ }^{\circ}$ journal and benefit from:

- Convenient online submission

- Rigorous peer review

- Immediate publication on acceptance

- Open access: articles freely available online

- High visibility within the field

- Retaining the copyright to your article

Submit your next manuscript at $>$ springeropen.com 